Красинский Владислав Вячеславович

доктор юридических наук, полковник, член Общественного консультативного научно-методического Совета при ЦИК России

\title{
О новых угрозах конституционному строю России в процессе подготовки и проведения выборов в Единый день голосования 18 сентября 2016 г.
}

Ключевые слова: выборы, избирательный процесс, конституционный строй, угрозы конституционному строю, экстремизм, организованная преступность, иностранное вмешательство в избирательный процесс.

Аннотаиия: автор анализирует новые угрозы конституционному строю, возникшие в ходе федеральных, региональных и местных выборов 2016 г. в России.

Keywords: elections, electoral process, constitutional order, threats to the constitutional order, extremism, organized crime, foreign intervention in the electoral process.

Abstract: The author analyzes the new threats to the constitutional order, which are concerned with federal, regional and local elections in 2016 in Russia.

Источник опубликования: Красинский B.B. Новые угрозы конституционному строю России в процессе подготовки и проведения выборов в Единый день голосования 18 сентября 2016 г. // Современное право. 2017. № 3. С. 12-19.

18 сентября 2016 г. в Единый день голосования на территории Российской Федерации состоялось 5300 избирательных кампаний всех уровней.

Выборы носили свободный, справедливый и траспарентный характер, позволили гражданам выразить свое волеизъявление и сформировать представительные органы власти. Вместе с тем в ходе выборов в ряде случаев возникали реальные угрозы конституционному строю, среди которых можно выделить как традиционные (попытки проникновения криминалитета в органы публичной власти, вмешательство иностранных государств и подконтрольных им международных организаций в избирательный процесс), так и новые угрозы (активизация экстремистской деятельности за счет 
сращивания отдельных праворадикальных и молодежных экстремистских структур (в том числе ультрарадикальных объединений футбольных болельщиков) с оппозиционными политическими силами; попытки срыва и дискредитации избирательной кампании в Крыму)).

Как и в ходе предыдущих выборных кампаний, серьезной угрозой конституционному строю являлась криминализация российских органов публичной власти ${ }^{1}$.

В современных условиях представители организованной преступности стремятся контролировать прибыльные сектора экономики, управлять бюджетными средствами, участвовать в принятии решений органами власти, влиять на законотворческий процесс. Инфильтрация криминальных лидеров, участников преступных групп и их связей в органы власти с помощью выборов позволяет решать большинство из этих задач.

Одним из показателей устремлений преступных организаций выступает официальная статистика избирательных комиссий об участии лиц с криминальным прошлым в избирательных кампаниях по параметру наличия судимости. Вместе с тем информационно-справочные учеты правоохранительных органов содержат и другие, не менее значимые криминологические показатели (данные о криминальных связях, распределении ролей в криминальных структурах, о процессуальных и следственных действиях, проведенных в отношении граждан органами предварительного расследования, а также иная информация об участии в деятельности преступных организаций).

Так, при подготовке выборов депутатов Государственной Думы Федерального Собрания Российской Федерации 7 созыва 2016 г. в ходе проведенной ЦИК России проверки 4384 кандидатов по спискам 14 партий и 1280 кандидатов, выдвинутых партиями по одномандатным округам, было

${ }^{1}$ Красинский В.В. Организованная преступность на выборах и в российских органах власти. М.: Юрлитинформ, 2014 . 224 с. 
выявлено 95 ранее судимых граждан, из которых 60 скрыли сведения об имевшихся у них судимостях ${ }^{1}$.

Применительно к субъектам Российской Федерации данная криминологическая статистика выглядит следующим образом. 5 граждан, имеющих судимость, было выдвинуто в Республике Татарстан по одномандатным округам на выборах депутатов Государственной Думы (представляли политические партии «Яблоко» (2), «Родина» (1), КПРФ (1) и «Единую Россию» (1). По федеральным спискам также выдвигалось 5 человек, привлекавшихся к уголовной ответственности (представляли партии «Единая Россия», «Справедливая Россия», КПРФ, «Союз Труда» и «Патриоты России»). В Чувашской Республике 2 самовыдвиженцам с криминальным прошлым было отказано в регистрации, в Карачаево-Черкесской Республике по «криминальному» фактору не допущен к регистрации 1 самовыдвиженец. В Краснодарском крае кандидатом по одномандатному округу от партии «Зеленые» был выдвинут лидер рейдерской группировки, специализирующейся на противоправном отчуждении у государства прав на земельные участки. 16 кандидатов были исключены из региональных списков в Красноярском крае. При проведении проверочных мероприятий избирательной комиссией и правоохранительными органами Пермского края выявлены 3 кандидата в депутаты Государственной Думы, аффилированных с лидером региональной организованной преступной группы (в том числе действующие депутаты законодательного органа государственной власти субъекта Российской Федерации и представительного органа власти муниципального образования). В Оренбургской области от участия в выборах отведено 4 кандидата, имеющих судимость (представители партии «Патриоты России»), в Челябинской области - 2 ранее судимых гражданина. 1 кандидату (партия «Справедливая Россия») избирательной комиссией Новосибирской

${ }^{1}$ Известия. 2016. 10 августа. В качестве кандидатов в депутаты Государственной Думы нового созыва к выборам было допущено 6502 представителя 14 из 76 зарегистрированных политических партий и 23 самовыдвиженца. 
области было отказано в регистрации в связи с сокрытием сведений о наличии непогашенной судимости.

Попытки личного выдвижения и регистрации на парламентских выборах предпринимали бывшие лидеры и активные члены организованных преступных групп, а также их родственные связи (Алтайский край, Иркутская, Оренбургская, Свердловская, Тульская области, Ханты-Мансийский автономный округ) ${ }^{1}$.

Новым элементом избирательной кампании стало проведение некоторыми партиями («Альянс Зеленых», «Единая Россия», «Парнас» и «Партия Роста») предварительного голосования по отбору кандидатов на выборы в Государственную Думу и в законодательные органы государственной власти субъектов Российской Федерации (т.н. «праймериз») $)^{2}$. Наиболее массовым было предварительное голосование партии «Единая Россия», состоявшееся 22 мая 2016 г.

Представители организованных преступных структур попытались использовать эту форму политической деятельности для легализации своих кандидатов. Правоохранительными органами были выявлены факты включения граждан, в отношении которых имелись сведения о связях с организованными преступными группами и совершении преступлений, в состав т.н. «территориальных групп» кандидатов при проведении праймериз в ряде округов Республики Адыгея, Красноярского края, Кировской области.

Часть выдвинутых и зарегистрированных кандидатов в депутаты Государственной Думы имела процессуальный статус подозреваемых (Тюменская область - представитель партии «Коммунисты России») и обвиняемых в совершении преступлений (Псковская область - кандидат от партии «Родина»; Амурская область - самовыдвиженец).

1 Выдвинутые на выборах кандидаты представляли интересы организованных преступных сообществ «Братское», «Уралмаш», «Центр», «Спортсмены» и др.

2 Процедура «праймериз» не урегулирована избирательным законодательством Российской Федерации и имеет рекомендательное значение. 
Устойчивое стремление представителей криминалитета к проникновению в органы публичной власти было характерно и для избирательных кампаний по выборам в региональные органы законодательной власти и представительные органы муниципальных образований.

Для наглядности приведем аналогичную криминологическую статистику. Так, в результате проведенной проверки кандидатов в депутаты Народного Собрания Республики Дагестан в отношении 80 кандидатов получены сведения о причастности к совершению экономических преступлений в составе организованных преступных групп, к обеспечению деятельности криминальных структур (12 кандидатов), к экстремистской деятельности (2 кандидата). В отношении 1 кандидата получена информация о его близких связях с осужденным боевиком-террористом.

При подготовке выборов в Орловский областной совет народных депутатов выявлено 12 ранее судимых кандидатов, 192 гражданина с криминальным прошлым баллотировались в представительные органы местного самоуправления Орловской области. В ходе проведения проверочных мероприятий избирательной комиссией Амурской области исключены из областных списков кандидатов в региональное Законодательное Собрание и не допущены к выборам как лица, не предоставившие сведения о судимостях, 22 гражданина. В Свердловской области в связи с сокрытием сведений о судимости отказано в регистрации 9 кандидатам в депутаты законодательного органа государственной власти субъекта Российской Федерации и 5 гражданам, баллотировавшимся в депутаты представительных органов муниципальных образований.

На региональных и местных выборах фиксировались попытки финансирования кандидатов со стороны действующих и бывших лидеров организованных преступных групп (Иркутская, Свердловская области, Красноярский край). Следует отметить, что «теневое» финансирование избирательных кампаний осуществлялось как по инициативе криминальных 
структур, так и по запросам заинтересованных кандидатов в депутаты и на выборные должности (помощь в погашении кредитов).

В Красноярском крае, Калининградской и Свердловской областях члены преступных организаций принимали скрытое участие в предвыборной агитации в пользу своих кандидатов.

Представителями криминалитета с целью воздействия на избирательный процесс продолжает практиковаться направление «бойцовспортсменов» на избирательные участки, где перед ними стоит задача воздействия на членов избирательных комиссий и сторонников политических оппонентов, а также провокации силовых действий под предлогом нарушений избирательного законодательства. При проведении местных выборов отмечались попытки вбросов избирательных бюллетеней членами таких «спортивных» бригад ${ }^{1}$.

После избрания ставленники криминалитета стремятся формировать свой рабочий аппарат с привлечением советников, помощников и консультантов, связанных с преступными организациями, оказывавшими поддержку в ходе избирательной кампании ${ }^{2}$.

Обобщение электоральной практики свидетельствует о том, что криминализация органов публичной власти в условиях подготовки и проведения выборов осуществляется в следующих формах:

- выдвижение и регистрация на выборах лидеров и активных членов организованных преступных групп, а также их родственных связей ${ }^{3}$;

- финансирование интересующих кандидатов и подкуп избирателей со стороны организованных преступных групп;

- распространение подложных и анонимных агитационных материалов;

${ }^{1}$ Подобная практика фиксировалась в республиках СКФО.

2 Такие факты отмечались в Кировской области.

3 С учетом повышения роли политических партий в избирательном процессе важнейшей задачей криминалитета является установление контроля организованных преступных групп над политическими партиями (региональными отделениями) и продвижение своих представителей в органы власти с использованием партийных структур. 
- организация вбросов избирательных бюллетеней и оказание силового воздействия на членов избирательных комиссий и сторонников политических оппонентов;

- привлечение избранными должностными лицами и депутатами в качестве помощников членов организованных преступных групп.

Угрозообразующие факторы криминализации органов публичной власти в условиях выборов связаны с низкой политической и правовой культурой организации и проведения выборных кампаний, ослаблением режима законности, коррупцией партийного и государственного аппарата, зависимостью официальной и теневой экономической деятельности от политической конъюнктуры в Российской Федерации.

Серьезной угрозой конституционному строю являются террористические и иные экстремистские проявления в условиях выборов.

Выборы дают возможность обнародования политических программ и участия сепаратистских, национал-радикальных и экстремистских организаций в массовых мероприятиях, открытой пропаганды их идеологических взглядов.

Формами реализации данной угрозы могут являться:

- протестные акции («антикризисные марши», «антивоенные марши», «марши несогласных», «антикоррупционные протесты» и др.);

- агитация, направленная на разжигание розни;

- подготовка и совершение преступлений террористического характера и экстремистской направленности с целью оказания влияния на ход избирательной кампании и результаты выборов;

- массовые беспорядки.

Выборы, как правило, широко освещаются в СМИ, поэтому любое противоправное посягательство, поданное под прикрытием оппозиционной или радикальной политической деятельности, приобретает широкий общественный резонанс. 
Основой инспирирования и активизации экстремистской деятельности в ряде случаев выступает сращивание праворадикальных и молодежных экстремистских структур с оппозиционными и парламентскими политическими силами.

Данная тенденция проявлялась на федеральном, региональном и муниципальном уровне.

Так, радикальный идеолог проекта «5.11.17» В. Мальцев в 2016 г. от партии «Партия народной свободы» (далее - «Парнас») был выдвинут кандидатом в депутаты Государственной Думы Федерального Собрания Российской Федерации ${ }^{1}$ В ходе избирательной кампании он предпринял попытку создать коалицию либералов, националистов и казаков.

При проведении предвыборной агитации лидерами «Парнаса» допускались высказывания радикального характера, что явилось основанием для подачи представителями партии «Гражданская платформа» административного искового заявления об отмене регистрации федерального списка кандидатов в депутаты Государственной Думы Федерального Собрания Российской Федерации седьмого созыва, выдвинутого партией «Парнас»². Отмечались факты ведения предвыборной агитации в пользу партии «Парнас» со стороны правых радикалов и националистов ${ }^{3}$.

${ }^{1}$ Доверенным лицом В. Мальцева стал Д. Демушкин - руководитель запрещенных в Российской Федерации экстремистских структур «Славянский Союз», «Славянская Сила» и этнополитического объединения «Русские». См. Решение Московского городского суда от 27 апреля 2010 г. о признании Межрегионального общественного движения «Славянский Союз» экстремистской организацией; Решение мирового суда Останкинского района г. Москвы от 17 марта 2014 г. о признании Д. Демушкина виновным в организации нового экстремистского сообщества - движения «Славянская Сила»; Решение Московского городского суда от 28 октября 2015 г. о признании этнополитического объединения «Русские» экстремистским и запрете его деятельности на территории России.

2 Определение Верховного Суда Российской Федерации от 12 сентября 2016 г. № АКПИ16-984 по административному исковому заявлению об отмене регистрации федерального списка кандидатов в депутаты Государственной Думы Федерального Собрания Российской Федерации седьмого созыва, выдвинутого политической партией «Парнас». Производство по делу было прекращено в связи с отказом «Гражданской платформы» от административного иска.

${ }^{3}$ В апреле 2016 г. националистическая организация «Комитет «Нация и Свобода» (КНС) призвала своих сторонников голосовать за партию «Парнас». 20 июля на сайте КНС 
В ходе выборов депутатов Государственной Думы Федерального Собрания Российской Федерации 2016 г. актив Хабаровского регионального отделения партии «Справедливая Россия» на безвозмездной основе использовал для агитационно-пропагандистской деятельности представителей ультрарадикальной фанатской группировки «IGF» (неформальное объединение болельщиков футбольного клуба «СкаЭнергия») $)^{1}$.

Аналогичные процессы были характерны и для ряда региональных и муниципальных выборных кампаний. В частности, лидеры и члены неформальных объединений футбольных болельщиков - молодежных группировок экстремистской направленности г. Самары принимали активное участие в предвыборных кампаниях различного уровня в качестве агитаторов и наблюдателей политических организаций («Партия прогресса», «Парнас»).

В отличие от легальной оппозиции, осуществляющей свою деятельность в рамках существующего законодательства, радикальная оппозиция преследует цели насильственного изменения конституционного строя и не ограничивает арсенал своих методов действий, средств и источников финансирования правовым полем. Лидерами и функционерами данных структур используются различные угрозообразующие факторы, в числе которых выступают:

- принятие государственными органами непопулярных политических решений в социально-экономической сфере (реформирование ЖКХ, пенсионная реформа, система налогообложения и др.) ${ }^{2}$;

был размещен список кандидатов по одномандатным округам, которых националисты рекомендовали поддержать на выборах.

${ }^{1}$ В число участников фанатской группировки «IGF» входят наиболее агрессивные представители праворадикального движения г. Хабаровска. Ряд членов «IGF» привлекался к уголовной ответственности за преступления экстремистской направленности и общеуголовные преступления.

2 Повышение тарифов на услуги ЖКХ, рост налогового бремени на физических и юридических лиц, повышение цен на продукты питания, лекарства и товары первой необходимости, увеличение задолженности по заработной плате, неудовлетворенность граждан ситуацией в области медицинского обеспечения, образования и транспорта негативно отражаются на отношении граждан к социально-экономической политике государства. 
- наличие очагов социальной напряженности в регионах с высоким уровнем безработицы и неблагоприятной криминогенной обстановкой ${ }^{1}$;

- снижение реально располагаемых доходов населения, девальвация национальной валюты и рост цен из-за санкционного давления США и стран Евросоюза ${ }^{2}$;

- высокая дифференциация населения по уровню денежных доходов ${ }^{3}$;

- проблемы и недостатки антикриминальной и антикоррупционной политики государства и др.

Существующие социально-экономические трудности могут использоваться для организации и координации различного рода протестных акций, дестабилизации общественно-политической ситуации и смены государственно-политического режима по сценариям "цветных" революций ${ }^{4}$.

В числе важных угроз конституционному строю необходимо выделить вмешательство иностранных государств и подконтрольных им международных организаций в избирательный процесс.

Данная угроза является элементом агрессивной политики США и их союзников в отношении России, которая направлена на демонизацию

1 По данным Министерства труда и социальной защиты РФ, в 2015 г. наиболее высокий уровень безработицы отмечался в Республике Ингушетия $(30,7 \%)$, Чеченской Республике $(16,8 \%)$, Республике Тыва $(21,7 \%)$, Республике Калмыкия $(11,4 \%)$, в Забайкальском крае $(10,4 \%)$. Проблемой остается высокий уровень безработицы среди молодежи $(24,3 \%)$. Отчетливо проявляется тенденция увеличения количества работников, занятых неполный рабочий день или находящихся в неоплачиваемом отпуске, а также роста безработицы среди граждан в возрасте старше 50 лет $(19,3 \%)$.

2 По данным Росстата, в 2015 г. 40\% населения РФ полагало, что его благосостояние ухудшилось в сравнении с уровнем 2014 г. Реально располагаемые доходы населения снизились на 5,3\%, среднемесячная зарплата сократилась на 9\%. Доля населения с денежными доходами ниже прожиточного минимума в общей численности населения увеличилась до $14,1 \%$ и составляет 20, 3 млн. человек. Доля детей в семьях с денежными доходами ниже прожиточного минимума составляет 26\%. // База данных Росстата Cbsd.gks.ru (дата обращения 05.05.2016 г.)

3 По данным Росстата, на долю 10 \% наиболее обеспеченного населения в РФ приходится 29,4 \% общего объема денежных доходов, а на долю $10 \%$ наименее обеспеченного населения - 2,1 \%. Коэффициент дифференциации денежных доходов в целом по России составляет 14,2. Его самый высокий уровень зафиксирован в Москве, Тюменской и Самарской областях, Ненецком автономном округе, г. Санкт-Петербурге, минимальные значения - в Тверской, Волгоградской, Костромской областях и Республике Алтай. // База данных Росстата Cbsd.gks.ru. (дата обращения 02.05.2016 г.)

4 Как отмечается в Стратегии противодействия экстремизму в Российской Федерации до 2025 г. (утверждена Президентом РФ 28 ноября 2014 г.), «основным способом дестабилизации социально-политической обстановки в РФ становится привлечение различных групп населения к участию в протестных акциях, в т.ч. несогласованных, которые впоследствии умышленно трансформируются в массовые беспорядки». 
руководства страны средствами пропаганды, дискредитацию российской государственности и смену государственно-политического режима в стране.

Удобным предлогом для достижения поставленных целей послужила возникшая в результате многолетних целенаправленных усилий США кризисная ситуация вокруг Украины. В ней отчетливо проявились попытки Вашингтона дискредитировать Россию в глазах Европы, максимально разрушить ее связи с европейскими государствами, лишить стороны выгод и преимуществ тесного взаимодействия.

В связи с вступлением Крыма в состав Российской Федерации, провозглашением ДНР и ЛНР на Юго-Востоке Украины зарубежные СМИ и политическое руководство США, Канады и Западной Европы вернулись к агрессивной риторике «холодной войны». Было предложено «изолировать» Россию и возродить «демократическую коалицию Запада времен «холодной войны» с главенствующей ролью Соединенных Штатов.

При подготовке выборов 2016 г. заинтересованными иностранными государствами предпринимались активные попытки дискредитации избирательной кампании в Крыму ${ }^{1}$. В условиях реализации украинским руководством реваншистских планов с использованием террористических методов и т.н. «мягкой силы» в ходе подготовки и проведения выборных кампаний 2016 г. зарубежные идеологи и координаторы антироссийской деятельности сделали ставку на украинских и крымско-татарских националистов, активистов псевдоправозащитных структур. Основными формами данной деструктивной деятельности в ходе избирательной кампании выступали:

18 сентября 2016 г. на заседании Верховной Рады Украины было принято обращение к парламентам, парламентским ассамблеям и международным организациям с призывом воздержаться от участия в наблюдении за выборами в Государственную Думу и не признавать их результаты. 12 сентября Российская Федерация получила официальную ноту МИД Украины о невозможности проведения в стране голосования на выборах в Государственную Думу. При этом было выдвинуто условие о согласии на проведение голосования на территории российских дипломатических учреждений, если Российская Федерация откажется от выборов в Крыму и исключит представителей полуострова из списков кандидатов. 
- блокирование работы и срыв голосования на отдельных избирательных участках с помощью массовых телефонных звонков о закладке взрывных устройств и анонимных электронных сообщений об актах терроризма ${ }^{1}$;

- воспрепятствование допуску избирателей на участки для голосования, расположенные на территории Украины²;

- умышленная порча предвыборной агитации;

- нанесение украинской символики и граффити в публичных местах;

- формирование через СМИ и социальные сети общественного мнения о необходимости бойкота выборов;

- порча избирательных бюллетеней антироссийскими лозунгами;

- дискредитация итогов голосования и результатов выборов на территории Республики Крым и г. Севастополя;

- заброска и попытки развертывания на территории Крыма диверсионноразведывательных групп Главного управления разведки Министерства обороны Украины ${ }^{3}$.

Вместе с тем, благодаря гражданской позиции жителей Крыма, четкой организации избирательного процесса, соблюдению законности и профессионализму сотрудников правоохранительных органов попытки воспрепятствовать волеизъявлению граждан, подорвать доверие к выборам и представительным органам власти были сорваны.

В качестве традиционного инструмента внешнего вмешательства в избирательный процесс задействовались ангажированные международные организации по наблюдению за выборами.

Для выборов в Единый день голосования 18 сентября 2016 г. было характерно расширение формата внешнего наблюдения за выборами и

1 Данная деятельность осуществлялась запрещенными в России организациями такими, как «Меджлис крымско-татарского народа» и «Хизб-ут-Тахрир аль Ислами»).

2 Такие попытки фиксировались в гг. Одесса и Киев.

${ }^{3}$ В августе 2016 г. ФСБ России была нейтрализована украинская диверсионноразведывательная группа, планировавшая теракты на объектах критической инфраструктуры и жизнеобеспечения населения Крыма. 8 ноября 2016 г. в г. Севастополе была задержана вторая диверсионно-разведывательная группа. 
активизация использования возможностей избирательного процесса в ущерб интересам защиты конституционного строя.

Так, Бюро по демократическим институтам и правам человека Организации по безопасности и сотрудничеству в Европе (БДИПЧ ОБСЕ) была развернута самая масштабная с 2003 г. миссия мониторинга избирательной кампании в 50 субъектах Российской Федерации ${ }^{1}$. В Российскую Федерацию были направлены 64 долгосрочных и 370 краткосрочных наблюдателей БДИПЧ ОБСЕ (для сравнения: на выборах 2011 г. в России работали 203 наблюдателя БДИПЧ ОБСЕ).

По прибытию в регионы наблюдатели провели консультации с кандидатами «демократически ориентированных» политических партий «Парнас», «Яблоко», «Открытая Россия», журналистами оппозиционных СМИ, а также руководством и координаторами движения «Голос». В ходе встреч осуществлялся целенаправленный сбор тенденциозной информации о социально-политической обстановке в России, нарушениях и злоупотреблениях в избирательном процессе, осуществлялось изучение перспективных молодежных активистов и ангажированных политических деятелей. Для формирования информационных поводов по дискредитации избирательной кампании, компрометации конституционных органов власти и управления задействовался потенциал региональных отделений движения «Голос» и аффилированных с ним псевдоправозащитных структур ${ }^{2}$. С привлечением зарубежных и оппозиционных СМИ предпринимались попытки тиражирования тенденциозной информации о нарушениях выборного

${ }^{1}$ При этом ОБСЕ и БДИПЧ отказались от мониторинга выборов в Крыму.

2 Министерство юстиции Российской Федерации 5 июня 2014 г. включило Ассоциацию некоммерческих организаций «В защиту прав избирателей «Голос» и Региональную общественную организацию в защиту демократических прав и свобод «Голос» в реестр некоммерческих организаций, выполняющих функции иностранного агента. 27 июля 2015 г. в этот реестр был включен Межрегиональный общественный фонд содействия развитию гражданского общества «Голос - Урал», а 4 сентября 2015 г. - Фонд в поддержку демократии «Голос» (в настоящее время ликвидирован). Указанные структуры попали в список иностранных агентов как организации, ведущие политическую деятельность при наличии финансирования из-за рубежа. 
законодательства со стороны представителей органов власти и парламентских партий в сочетании с замалчиванием аналогичных нарушений, допущенных иными субъектами избирательного процесса.

Как показывает многолетняя практика выборов, реализация угрозы иностранного вмешательства в избирательный процесс возможна в следующих формах:

- оказание финансовой и консультативной помощи некоммерческим организациям, оппозиционным партиям и движениям, нацеливание их действий на дестабилизацию социально-политической обстановки в стране, подрыв доверия населения к законным органам власти и избирательному процессу;

- методическая помощь интересующим избирательным штабам, кандидатам и их доверенным лицам;

- создание финансируемой извне межрегиональной электоральной сети наблюдения за выборами, ориентированной преимущественно на фиксацию нарушений избирательного законодательства и организацию альтернативного подсчета голосов;

- формирование и поддержка молодежных структур «гражданского неповиновения»;

- инспирирование протестной активности в обществе с использованием подконтрольных СМИ и сети Интернет;

- оказание давления на иностранных и международных наблюдателей;

- объявление официальными лицами иностранных государств и международных организаций (Государственный департамент США, Европарламент, Парламентская Ассамблея Совета Европы, Бюро по демократическим институтам и правам человека и др.) выборов недемократичными, а их результатов - сфальсифицированными.

В основе всех этих форм лежат технологии консолидации антигосударственных политических сил, вовлечения населения в протестные акции и их умышленного трансформирования в массовые беспорядки. 
Угрозообразующие факторы, связанные с возможностью внешнего вмешательства в избирательный процесс, представлены: агрессивными геостратегическими установками лидеров ряда иностранных государств (их союзов) по «сдерживанию» России и вмешательству в ее внутренние дела в целях неконституционной смены власти; увеличением масштабов и скоординированности применения отдельными государствами информационных технологий, направленных на подрыв суверенитета и территориальной целостности Российской Федерации; «двойными стандартами» во внешней политике и гуманитарной сфере; использованием правозащитных концепций и института международного наблюдения за выборами в качестве инструмента политического давления на органы власти и управления.

C учетом возможности формирования и обострения угроз конституционному строю в условиях выборов, зависимости потенциала угроз от соответствующих угрозообразующих факторов главные устремления антироссийских сил в ходе подготовки к Единому дню голосования 18 сентября 2016 г. были направлены на формирование оппозиционной коалиции, способной по «украинскому сценарию» инспирировать протестные настроения и в последующем изменить политический курс руководства страны неконституционными методами. Важнейшая роль в этом процессе, как и ранее, отводилась организации незаконных массовых публичных мероприятий с участием молодежи.

Благодаря доверию населения к главе государства, широкой поддержке проводимой органами власти политики дестабилизации социальнополитической обстановки, подрыва авторитета государства и антиконституционных проявлений удалось избежать.

В ходе выборов 18 сентября 2016 г. проявились новые угрозы конституционному строю, которые позволили вскрыть слабые места в системе защиты конституционного строя и определить дополнительные направления 
работы уполномоченных органов по защите конституционных основ организации и функционирования государственной власти.

Эти угрозы необходимо учитывать организаторам выборов и правоохранительным органам. Так, требуется комплексная предупредительно-профилактическая работа в молодежной и праворадикальной среде. Необходимо дальнейшее совершенствование контроля за финансированием некоммерческих объединений и общественных организаций, соответствием деятельности филиалов и представительств иностранных неправительственных организаций уставным целям и задачам, соблюдением ими российского законодательства. Нуждается в развитии противодействие на системной основе коррупции и криминализации государственных и муниципальных органов публичной власти. Востребована наступательная работа по пресечению деятельности агитационных площадок антигосударственной пропаганды в СМИ и Интернете. Представляется целесообразным усиление антитеррористической защищенности критически важных объектов в Крыму и других приграничных с Украиной субъектах Российской Федерации.

Нейтрализация традиционных и пресечение новых угроз должны дополняться устранением реальных причин и условий, формирующих уязвимости системы социально-экономических и политических отношений, подлежащих защите со стороны государства. 